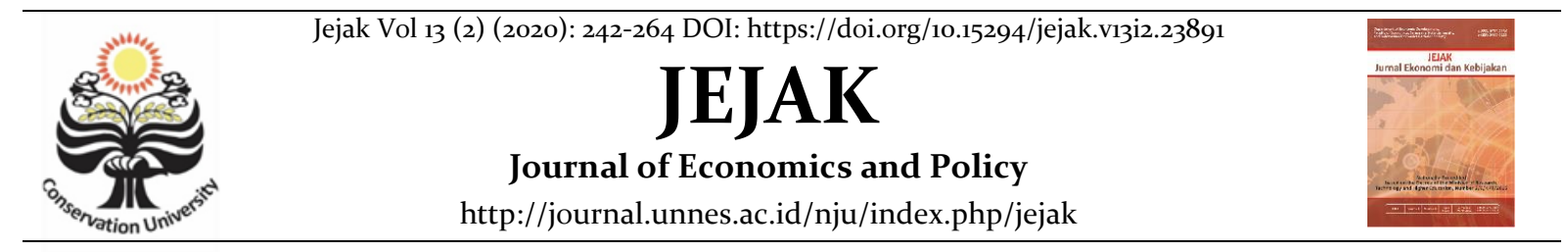

\title{
The Reluctance Phenomenon of Islamic Banks to Offer Profit-Loss Sharing Financing
}

\author{
Sabrina ${ }^{1}{ }^{2 \bowtie}$ M. Shabri Abd Majid \\ ${ }^{1,2}$ Faculty of Economics and Business, Syiah Kuala University \\ Permalink/DOI: https://doi.org/10.15294/jejak.v13i2.23891 \\ Received: May 2020; Accepted: July 2020; Published: September 2020
}

\begin{abstract}
This study contributes to the existing literature on the phenomenon of lower valume of Profit-Loss Sharing (PLS)-based products offered by Islamic banks by comprehensively discussing and analyzing the issue from the internal, external, and regulation perspectives, taking the case of PT. Bank Aceh Syariah (BAS) in Indonesia. Using a grounded theory approach, this study interviews selected informants who are knowledgeable in Islamic economics, banking, and financial theories and practices, including experts, practitioners, customers, and regulators. Viewed from three aspects, namely: internal, external, and regulation, the study found that, from the internal aspect, the problem of the low volume of PLS-based financing products is caused by six factors, namely: high risk, lack of quality and quantity of human resources, complicated handling, lack of banking product innovation, asymmetric information, and lack of socialization. Meanwhile, from the external aspects, it is caused by three factors, namely: moral hazard, lack of community's knowledge of Islamic banking products, and low demand. Finally, from the aspect of the regulation, it is caused by a lack of supportive regulation. By tackling these issues, it is believed that the Islamic bank could offer more PLS-based products that finally contribute to the prosperity of the public.
\end{abstract}

Key words : Bank Aceh Syariah, Islamic bank regulation, Risk avoidance, PLS financing.

How to Cite: Sabrina, S., \& Majid, M. (2020). The Reluctance Phenomenon of Islamic Banks to Offer Profit-Loss Sharing Financing. JEJAK: Jurnal Ekonomi dan Kebijakan, 13(2). doi:https://doi.org/10.15294/jejak.v13i2.23891

\footnotetext{
Corresponding author : M. Shabri Abd Majid

Address: Faculty of Economics and Business, Syiah Kuala

University

E-mail: mshabri@unsyiah.ac.id
} 


\section{INTRODUCTION}

The banking institution plays a crucial role in promoting economic development (Imam \& Kpodar, 2016; Setiawan, 2019). As an intermediary institution, a bank collects funds from the surplus units and channels them to the deficit units. In so doing, there is a need for clarity in the banking operational system. The emergence of many financial institutions that apply Islamic principles lately is an interesting phenomenon to be observed and researched. From an Islamic perspective, the activities of the bank are part of muamalah that regulates human relations. The regulation of banking institutions in the Islamic perspective is based on the principle in usul fiqh which states that "maa laa yatimm al-wajib illa bihifa huwa wajib", that is, something that must exist for mandatory needs is mandated to be provided. Seeking sustenance through economic activity must be done. Therefore, in modern times, without the presence of a banking institution, economic activity would not be run smoothly, thus the existence of banks in the economy becomes mandatory (Karim, 2010).

According to Majid (2014), historically, Islamic banking entities in Indonesia have been started since 1983 with the release of 1983 packages containing registration documents in the banking sector, one of which contains regulations that allow banks to provide interest-free banks. The policy on the banking sector conveyed by the Minister of Finance, the Republic of Indonesia in the October 1988 Package, containing banking deregulation which provided convenience for new Islamic banks. Until 1991, Bank Muammalat Indonesia (BMI) was established as the only commercial bank operated with the Islamic principles.

Since the global economic crisis hit the United States in August 2007, Islamic banks have been increasingly being looked after and targeted due to their resilience. Amid waves of the global economic crisis, Islamic banks and other Islamic financial regulations were still able to reap profits and also recruit new employees. The Islamic banking industry is expected to grow to $10 \%$ with total assets reaching USD 1 in 2010. On the other hand, the conventional banks that were considered "too big to fail" incurred huge losses and even went to bankruptcy hit by the global economic crisis (Majid, 2011).

Although the Islamic banking industry has been developing rapidly in Indonesia but its achievement is still far from the target. That is because there are still problems that hampering the Islamic banking business. There are still many people who think that Islamic banks are the same as conventional banks. This general perception exists among the public, so it is no wonder they are still reluctant to become customers and apply to finance from Islamic banking institutions. This can be seen from the slow growth of the Islamic banking industry, even though their potentials are huge considering Indonesia as the most Muslim populous country in the world.

One form of Islamic bank business is to provide financing and conduct other activities based on Islamic principles and following the provisions stipulated by the central bank of Indonesia, Bank Indonesia. In its implementation, Islamic banks try to apply the values of justice brought by the Islamic economic system (Zaaba \& Hassan, 2019). Efforts to establish the Islamic banks are to provide avenues for saving and financing activities that are free from interest or what is called usury (riba). Islamic banking provides interest-free services to its customers. Interest is prohibited in all forms of transactions. Islamic banking institution that is operated based on the PLS system; parties, customers, and banks would share profits or incur losses together. Thus, the PLS system echoes the value of 
togetherness (ta'awun), justice (al-adl), and brotherhood (ukhuwah) (Majid, 2014a).

Currently, there are, at least, seven financing-based contracts used in Islamic banking, namely: mudharabah, musharakah, murabahah, salam, istishna, ijarah, and qardh. However, according to Ascarya (2014), the main and most important Islamic banking contract agreed by the ulama is a contract with a PLS scheme, comprising mudharabah (trustee PLS) and musharakah (joint venture PLS). These contracts are based on the principle "al-ghunmu bi alghurmi" or "al-kharãj bi al-dhomãn", which means that there is no share in profits without taking part in risks or for any real economic benefits there must be real economic costs.

Therefore, Islamic banking should develop and provide financing based on PLS systems, as it has several positive impacts on the economy (Beik, 2006; and Majid, 2014a). Islamic banks promote the real sector (Kassim, 2016), provides higher profit rate compared to the interest rest offered by the conventional banks, encourages the growth of entrepreneurs and investors who are willing to involve in risky business decisions, reduces the chances of an economic recession and financial crisis (Yüksel \& Canöz, 2017), and offers an alternative solution to the existing banking problem of over-liquidity by providing mudharabah and musharakah based products.

Table 1. Composition of Islamic Banking Products, 2015-2020 (IDR Billion)

\begin{tabular}{|c|c|c|c|c|c|c|c|}
\hline \multicolumn{2}{|c|}{ Islamic Banking Products } & \multicolumn{5}{|c|}{ Year } & \multirow[b]{2}{*}{ Mean } \\
\hline & & 2015 & 2016 & 2017 & 2018 & 2019 & \\
\hline \multirow{8}{*}{ PLS } & Mudharabah & 14,207 & 15,292 & 17,090 & 15,866 & 13,779 & 15,247 \\
\hline & Growth (\%) & - & 7.64 & 11.76 & -7.16 & -13.15 & -0.23 \\
\hline & Musharakah & 49,416 & 78,421 & 101,561 & 129,641 & 157,491 & 103,306 \\
\hline & Growth (\%) & . & 58.70 & $29 \cdot 51$ & 27.65 & 21.48 & $34 \cdot 33$ \\
\hline & Share (\%) & 32.25 & 37.79 & 41.53 & $45 \cdot 44$ & 48.22 & 42.15 \\
\hline & Growth (\%) & - & 17.17 & 9.91 & 9.42 & 6.11 & 10.65 \\
\hline & Total & 63,623 & 93,713 & 118,651 & 145,507 & 171,270 & 118,553 \\
\hline & Growth (\%) & - & 47.29 & 26.61 & 22.63 & 17.71 & 28.56 \\
\hline \multirow{13}{*}{ Non-PLS } & Murabahah & 115,979 & 139,536 & 150,276 & 154,805 & 160,654 & 144,250 \\
\hline & Growth (\%) & - & 20.31 & $7 \cdot 70$ & 3.01 & 3.78 & 8.70 \\
\hline & Istishna & 630 & 878 & 1,189 & 1,609 & 2,097 & 1,281 \\
\hline & Growth (\%) & - & $39 \cdot 37$ & 35.42 & $35 \cdot 32$ & 30.33 & 35.11 \\
\hline & Ijarah & 11,418 & 9,150 & 9,230 & 10,597 & 10,589 & 10,197 \\
\hline & Growth (\%) & - & -19.86 & 0.87 & 14.81 & -0.08 & -1.06 \\
\hline & Qardh & 5,628 & 4,731 & 6,349 & 7,674 & 10,572 & 6,991 \\
\hline & Growth (\%) & - & $-15 \cdot 94$ & 34.20 & 20.87 & 37.76 & 19.22 \\
\hline & Salam & o & o & 0 & o & 0 & o,oo \\
\hline & Share (\%) & 67.75 & 62.21 & 58.47 & $54 \cdot 5^{6}$ & 51.78 & 57.85 \\
\hline & Growth (\%) & - & -8.17 & -6.02 & -6.69 & -5.09 & -6.49 \\
\hline & Total & 133,655 & 154,295 & 167,044 & 174,685 & 183,912 & 162,718 \\
\hline & Growth (\%) & & 15.44 & 8.26 & 4.57 & 5.28 & 8.39 \\
\hline \multirow{2}{*}{ Total } & Overall & 197,278 & 248,008 & 285,695 & 320,192 & 355,182 & 281,271 \\
\hline & Growth (\%) & - & 25.71 & 15.20 & 12.07 & 10.93 & 15.98 \\
\hline
\end{tabular}

Source: Sharia Banking Statistics (2020) - presented with modifications. 
However, since its establishment in 1991, the islamic banks have offered more non-pls-based financing products, comprising murabahah, salam, istishna, ijarah, and qardh, while the pls-based financing products, namely; mudharabah and musharakah have been relatively smaller. As illustrated in table 1, murabahah has been the most popular islamic banking product, while salam has not been introduced by islamic banks. Over the period 2015 to 2019, on the average, the proportion of the pls-based products was only $42.15 \%$ as compared to the non-pls-based products that accumulated to $57.85 \%$. Although the proportion of the plsbased products has, on average, increased from $32.25 \%$ in 2015 to $37.79 \%$ in $2016,41.53 \%$ in $2017,45.44 \%$ in 2018 and to $48.22 \%$ in 2019, but these figures are still far below the expectation. The pls-based products should dominate islamic banking products, if the banks expected to promote the real sector of the economy and, consequently, reduce poverty rate, income disparity, and unemployment rates.

Table 1 also shows that PLS-based products have increased from IDR 63,623 billion in 2015 to IDR 118,553 billion in 2019 . Similarly, the Non-PLS-based products have also increased from IDR 133,655 to IDR 162,718 2019. However, if looking at the percentage changes in the proportion of the PLS-based products, it has been showing an increasing trend, on the average, by $10.65 \%$ during the 2015-2019 period. On the other hand, the percentage changes in the proportion of the Non-PLS-based products have been declining, on average, by $-6.49 \%$ during a similar period. Although, this shows a promising trend for Islamic banks to offer more PLS-based products, but the changes have been too slow. These facts further show the reluctance of the Islamic banks to offer more of their products based on the PLS-scheme (Sharia Banking Statistics, 2020).

The reluctance of the Islamic bank to offer more PLS-based products also exercised by PT. Bank Aceh Syariah (BAS), the provincial bank of the government of Aceh, Indonesia. Table 2 illustrates that the murabahah (Non-PLS-based products) has been the most popular Islamic banking product offered by BAS, amounting to IDR 21,170,717 million in 2017, IDR 20,905,668 million in 2018, and IDR 21,240,284 million in 2019. Meanwhile, the musharakah (PLS-based product) offered by the BAS only IDR $1,009,828$ in 2017, IDR 1,270,002 in 2018, and IDR $1,237,899$ in 2019. It shows that, on average, the proportion of the PLS-based products offered by the BSA only amounting to $5.50 \%$, as compared to 94.50\% of its Non-PLS-based products over the 2017-2019 period (Bank Aceh Syariah, 2020).

These facts are too surprising since BSA is operated in the only province in Indonesia that has been granted by the central government of the Republic of Indonesia for the provincial government of Aceh to implement Islamic law in all aspects of life. With $98.21 \%$ of the Muslim population $(98.21 \%)$ that adheres to the Shari'a, Aceh province should carry out economic activities fully in harmony with the Islamic injunctions, including bank. However, in the last three years (2017-2019), the share of PLS-based products although has shown an increasing trend, but it only experienced trivial changes from $4.55 \%$ in 2017 to $5.72 \%$ in 2018 and $6.21 \%$ in 2019.

On the other hand, the share of Non-PLSbased products has experienced only a small decrease from $95.45 \%$ in 2017 to $94.28 \%$ in 2018 , and $93.79 \%$ in 2019 (Bank Aceh Syariah, 2020). If the existing practices of the BSA are continued and no reformative changes are made, it is strongly believed that the bank would fail to promote economic justice, reduce poverty, income disparity, and unemployment rates, considering Aceh is one of the provinces that recorded high poverty, disparity, 
unemployment, and economic growth in the Sumatran region. Besides, the presence of BSA would fail to promote the implementation of Islamic law, especially Islamic economic practices in the province.

Table 2. Composition of Bank Aceh Syariah Products, 2015-2019 (IDR Million)

\begin{tabular}{|c|c|c|c|c|c|}
\hline \multirow{2}{*}{\multicolumn{2}{|c|}{ Islamic Banking Products }} & \multicolumn{3}{|c|}{ Year } & \multirow{2}{*}{ Mean } \\
\hline & & 2017 & 2018 & 2019 & \\
\hline \multirow{7}{*}{ PLS } & Mudharabah & - & - & - & - \\
\hline & Musharakah & $1,009,828$ & $1,270,002$ & $1,433,867$ & $1,237,899$ \\
\hline & Growth (\%) & - & $25 \cdot 76$ & 12.90 & -13.67 \\
\hline & Share (\%) & $4 \cdot 55$ & 5.72 & 6.21 & $5 \cdot 50$ \\
\hline & Growth (\%) & - & $25 \cdot 76$ & 8.40 & -11.31 \\
\hline & Total & $1,009,828$ & $1,270,002$ & $1,433,867$ & $1,237,899$ \\
\hline & Growth (\%) & - & 25.76 & 12.90 & -13.67 \\
\hline \multirow{12}{*}{ Non-PLS } & Murabahah & $21,170,717$ & $20,905,668$ & $21,644,466$ & $21,240,284$ \\
\hline & Growth (\%) & - & -1.25 & 3.53 & -1.87 \\
\hline & Istishna & - & - & - & - \\
\hline & Salam & - & - & - & - \\
\hline & Qardh & 4,451 & 9,643 & 27,789 & 13,961 \\
\hline & Growth (\%) & - & 116.65 & 188.18 & $-49 \cdot 76$ \\
\hline & Ijarah & 757 & 656 & 1,538 & 984 \\
\hline & Growth (\%) & - & $-13 \cdot 34$ & 134.45 & -36.04 \\
\hline & Share (\%) & 95.45 & 94.28 & 93.79 & 94.50 \\
\hline & Growth (\%) & - & -1.23 & -0.51 & 0.75 \\
\hline & Total & $21,175,925$ & $20,915,967$ & $21,673,793$ & $21,255,228$ \\
\hline & Growth (\%) & - & -1.23 & 3.62 & -1.93 \\
\hline \multirow{2}{*}{ Total } & Overall & $22,185,753$ & $22,185,969$ & $23,107,660$ & $22,493,127$ \\
\hline & Growth (\%) & & 0.00 & 4.15 & -2.66 \\
\hline
\end{tabular}

Source: (Bank Aceh Syariah, 2020) - presented with modification.

As one of the financial institutions, BSA has a crucial role in driving the economy of the people in Aceh in line with the Islamic economic principles. For this reason, BAS, a financial institution owned by the Aceh provincial government, which at the beginning was formed and operated with conventional principles and has been converted to a full-fledged Islamic commercial bank based on the decision of the Board of Commissioners of the Financial Services Authority (Otoritas Jasa Keuangan OJK), No. KEP-44/D.03/2016 dated September 1, 2016, concerning the granting of a license for Changing Business Activities of Conventional Banks to Islamic Commercial Banks of PT. Bank Aceh. With this conversion, BSA is expected to be able to introduce PLS-based financing which is a major milestone of Islamic banks to provide the Muslim community an interest (riba)-free transaction. Muslim community could free themselves from dealing with the interest (riba)based transactions that are prohibited in Islam, as mentioned in the Holy Quran, Chapter alBaqarah verse 275 (Departemen Agama Republik Indonesia, 2005).

The reluctance of Islamic banks, including BAS to offer more PLS-based financing products has not only been the phenomenon of in Indonesia, but it has been a global phenomenon (Warninda et al., 2019). Globally, murabahah (Non-PLS-based financing products) has been the most popular product offered by Islamic 
banks. If these conditions continue to occur, it is not impossible that mudharabah- and musharakah-based financing which is the main icon of Islamic banks will be abandoned if the banks do not make reformative improvements in their financing scheme.

According to Ascarya \& Yumanita (2005), the low phenomenon of PLS-based financing is an important issue that needs to be discussed. Various problems and appropriate solutions need to be sought by the Islamic banks to increase PLS-based financing products. Moreover, the low share of PLS-based financing tends to be a multidimensional problem that has been happening for a long time and there has been no tendency to change.

Previous studies have adopted both qualitative (Ascarya \& Yumanita, 2005; Nurhasanah, 2010; Nabhan, 2010; and Adnan \& Purwoko, 2015) and quantitative (Andraeny, 2011; Khanifah, 2015; Annisa \& Yaya, 2015; Choirudin \& Praptoyo, 2017; and Aprilia \& Mahardika, 2019) approach to investigate factors influencing the small proportion of PLS-based financing products offered by the Islamic banks.

Using the Analytic Network Process technique, Ascarya \& Yumanita (2005) found that the main causes of the lack of PLS-based financing of Islamic banks in Indonesia were due to the lack of understanding and quality of Islamic bankers and supports from regulations. Another study by Nurhasanah (2010) stated that the issue of the low volume of PLS-based financing might be related to its risk level. From the perspective of Islamic bank management, Adnan and Purwoko (2015) found several factors influencing the low volume of PLS-based financing, comprising the risk, uncertainty, report mechanism, high NPF, customer's tranparency, Islamic human resource capacity, and lack of trust.
Since the PLS-financing product is based on the principle of trust, thus the low level of mudharabah and musharakah schemes have been due to higher risks of the products. Nowadays, it is not easy to find people with trust. Meanwhile, murabahah (non-PLS-based financing product) is a cost-plus sale transition, which contains a very low level of risk that has attracted more Islamic banks to offer this kind of product. Finally, Nabhan (2010) categorized customers of Islamic banks into two groups, risk-averse customer and risk-taking customer. The inability of Islamic banks to maintain and improve their payment capabilities for riskaverse depositors and provides the best return for risk-taking investors caused the Islamic banks to offer less of the PLS-based financing products.

Another group of studies has explored quantitatively the causes of the low volume of PLS-based products among the Islamic bank in Indonesia. For example, using the partial least square approach, Andraeny (2011) found that the low volume of PLS-based financing of Islamic banking in Indonesia during 2006-2010 was positively influenced by the depositors' funds and PLS rate and insignificantly influenced by non-performing financing. Khanifah (2015) researched the effects of the Bank Indonesia rate, Non-Performing Financing (NPF), exchange rate on the level of financing of the Bank Mega Syariah over the period from 20102012 and found that all these factors have no insignificant effect on the PLS-based financing. Annisa and Yaya (2015) examined the impact of third-party funds, profit-sharing rate, and NPF on the volume of PLS-based financing for the period from June 2010 to September 2013. Using multiple linear regression analysis, they recorded that all variables have a significant impact on PLS-based financing. 
Furthermore, Choirudin and Praptoyo (2017) investigated the effects of mudharabah deposits, capital adequacy, NPF, financing to deposit ratio, and operating expenses on the mudharabah financing of 10 Islamic banks during the 2012-2015 period in Indonesia. Using multiple linear regression, they found that mudharabah deposits, capital adequacy, and financing to deposit ratio had positively influenced mudharabah financing, NPF had negatively influenced mudharabah financing, and operating expenses did not influence mudharabah financing. Finally, Aprilia and Mahardika (2019) empirically explored the effects of capital adequacy ratio, NPF, and third party fund on PLS-based financing of 7 Islamic banks in Indonesia over the 2011-2016 period using the panel multiple regression analysis. Only third party fund deposits were found to have a significant effect on the PLS financing, while other variables were not.

The above-observed facts and reviewed studies show that although the issue of a small volume of PLS-based products offered by Islamic banks has been an old phenomenon, but no significant improvement has been made by the banks to increase offering PLS-based financing products, as suggested by many the contemporary Islamic economists worldwide. Thus, this pressing issue becomes more relevant and it is timely be researched and to provide concrete and comprehensive recommendations to be implemented for the banks to offer more PLS-based products, thus making Islamic banks more Islamic. In addition, the above-reviewed qualitative studies have only explored the causes of the low volume of the PLS-based financing offered by the Islamic banking institution at large, but none of them has focused its analysis on the Islamic banks in Aceh, the only province that has implemented Islamic law in Indonesia. Similarly, the above- reviewed quantitative studies have explored the causes of the low volume of the PLS-based products by only focusing on banks' characteristics and macroeconomic variables, while the internal, external, and regulation factors determining the reluctance of Islamic banks to offer more PLS-based products and their resistance to keep offering more murabahah and other Non-PLS-based products have been not reassessed.

Against these backdrops, thus the present study intends to comprehensively analyze the main causes of Islamic bank reluctance to offer more PLS-based financing products, taking Bank Aceh Syariah (BSA) as the case of study. In analyzing the issue, the internal, external, and regulation factors will be comprehensively discussed using the grounded theory approach.

The findings of this study are hoped to provide a comprehensive understanding of the reluctance of the Islamic bank to offer more PLS-based financing products and resistance to offering more Non-PLS-based products. Besides, this study also hopes to provide concrete recommendations for the Islamic banks to continuously increase offering PLS-based financing products and at the same time to reduce significantly offering Non-PLS-based products so that the Islamic banking institution could promote the real economic sector and, consequently, contribute to the government economic programs of alleviating poverty, reducing income disparity and unemployment rate. In short, these findings are expected to provide references for the Islamic banks and regulators in designing strategic policies to make Islamic banks more Islamic.

The rest of this study is organized into the following sequences. Section 2 highlights the research method, followed by the discussion on the findings in Section 3. Finally, Section 4 provides the conclusions and suggestions for further research. 


\section{METHOD}

The object of this study is PT. Bank Aceh Syariah (BSA) located in the Aceh Province, Indonesia. Since the objective of the study is described and analyze the problems of lack of PLS-based financing products offered by an Islamic bank, taking the case of BSA, thus the qualitative approach is identified to be the most suitable research method adopted in the study. Specifically, the study uses the grounded theory method. Grounded theory method is a method used in basic research that is directed at finding or strengthening a relevant theory by describing, evaluating, and analyzing the basic principles and rules that exist, then deriving conclusions that form the basic principles of the theory (Birks \& Mills, 2015).

The qualitative data are used in this study. These data are in the form of verbal words and not in the form of numbers. These data cannot be measured on a numerical scale and provide a general description of research objects, in the form of perceptions and opinions of the selected informants about the causes of the low volume of PLSbased financing of BSA.

The qualitative data used in this study are the form of primary data, which are collected directly from direct observations on the object of research by an interview the selected informants on matters relating to the factors influencing the lack of PLS-based financing of Islamic bank. Besides, secondary data are also gathered to support the primary data obtained through the literature, previous related journals, books, document, and reports relating to the topic of the study.

The population in this study is all the BSA stakeholders, comprising customers, Islamic scholars, academicians, internal bank, Shariah supervisory board members, and regulators. The purposive sampling technique is used to selected informants comprise several parties who have experience and are able explain their thoughts in more depth to get more in-depth information about the topic of study. Informants who are wellversed on the PLS-based products, including Islamic bankers (i.e., Executive Director, Manager of Financing Division, and Manager of Marketing Division) of the BSA, bank customers, Islamic scholars (i.e., Academicians, Sharia Supervisory Board Member, and Ulama), and regulators (i.e., Head of Financial Services Authority - Otoritas Jasa Keuangan (OJK) and Head of Bank Indonesia, Representatives of Banda Aceh, Indonesia) were selected for interview. Three people from each category of informants were interviewed, making a totality of 12 informants all together.

In order to maintain the independence and confidentiality of informants, when discussing and analyzing their opinions, the study will mention their names with initials. For example, for 3 informants from the category of Islamic bankers the initials $\mathrm{IB}_{1}, \mathrm{IB}_{2}, \mathrm{IB}_{3}$ are given. Likewise, for informants from the category of Islamic scholars, the initials IS1, IS2, and $I_{3}$ are given. Furthermore, for informants from categories of bank customers and regulators, the initials $\mathrm{BC}_{1}, \mathrm{BC}_{2}, \mathrm{BC}_{3}$, and $\mathrm{RG}_{1}$, $\mathrm{RG}_{2}, \mathrm{RG}_{3}$ are, respectively, given. Structuredopen ended questionnaires were prepared as the guideline for the interview and constructed based on the informants' background. On average, the interview was designed for a half hour.

Sequentially, this study is conducted based on the following four steps, namely: i) data collection; ii) data reduction; (iii) data display; and (iv) conclusion drawing and verification. In the first step, the data are collected from the informants and gathered form references, reports, and so on. In the second step, the collected data are reduced or reconfigured. The data are condensed and transformed for the sake of manageability and intelligibility of the addressing issues. In the 
third step, the data is displayed in an extended piece of text or a diagram, chart, or matrix to provide an organized and compressed information. At this stage, additional isssues could emerge from the data that go beyond those first discovered during the initial process of data collection and reduction. Finally, the conclusion is drawn and verified based on the analyzed data and integrally linked to conclusion drawing, entails revisiting the data as many times as necessary to cross-check the emergent conclusions (Miles et al., 2014). In short, the data are collected from both secondary and primary sources are reduced and adjusted following the needs of the study, displayed for in-depth-analyses, and finally, the conclusions are made and verified.

\section{RESULTS AND DISCUSSION}

This part This study discovers and describes the factors influencing the reluctance of PT. Bank Aceh Syariah (BSA) to offer more PLS-based financing products. As mentioned in the earlier section of the study, to get an in-depth-analysis and provide more comprehensive findings, these factors are viewed from three different aspects (i.e., internal bank, external bank, and regulation). For these purposes, three informants from the groups of Islamic bankers, bank customers, Islamic scholars, and regulators were interviewed. During the interview, the structured-open ended questionnaires that have been prepared were used as the guideline.

In the interview process, several steps have been taken to analyze the data. The first step is to prepare data for analysis, including interviewing informants, taking field notes, sorting important data or information depending on the purpose of the study. At the time of the interview, the results or information were recorded using a Smartphone audio recorder. Each respondent spends approximately 30 minutes in the interview process with questions that are designed as easily as possible so that they could easily respond to. Furthermore, to obtain in-depth information, several additional questions were posed to follow up the informants' opinions following the objective of the study.

The next step is data analysis, which is looking and reading carefully all data, giving a general understanding of research information and translating the meaning of the overall information from the interview results, namely what are the main factors that the informants considered. The next step in data analysis is the interpretation of the results and discussion. This includes scrutinizing the results of the study, confirming the results of the study by comparing it to the previous relevant studies. Finally, the study summarizes and makes conclusions and suggestions for future research.

The informants' feedbacks to the research problem formulation, namely analyzing factors causing the reluctance of the Islamic bank to offer more PLS-based financing products are reported and discussed from three aspects, namely: internal bank, external bank, and regulation.

The perspective of the internal aspects of the bank, almost all informants gave the same opinion about what caused the lack of PLSbased financing at BAS, namely in terms of high-risk factors. According to them, there are several from internal aspects of the bank that caused the reluctance of the bank to offer more PLS-based products, including:

High risk is the main problem that caused the lack of PLS-based financing of the Islamic bank. The bank as the owner of capital is very risk-averse, the bank is afraid of the uncertainty that will occur to cause the bank to bear huge losses. Because in PLS-based financing there are 
risks that might occur. Therefore the bank wants to minimize the risks that exist in the PLS-based financing by switching to NonPLS based financing such as murabahah. The risk of Non-PLS-based financing is lower than the risk of PLS-based financing. As stated by an Islamic scholar (IS1), who is the professor in Islamic economics, as below:

"... why is the PLS-based product in the Islamic bank low? Due to risk factors, it means that the Non-PLS-based financing has lower risk compared to the risk of PLS-based financing. While banks want to reduce the risks to their financing, therefore, the bank prefers PLS-based financing products ..."

The high risk is the main cause of the low volume of PLS-based financing, similar to the statement of Adnan \& Purwoko (2015). He stated that the first factor of lack of PLSbased financing of mudharabah is high risk. The bank as the owner of the fund does not want to suffer a large loss, thus the bank in providing financing opts to avoid the high risk.

Several risk indicators are causing the lack of PLS-based financing in Islamic banking, including the effect of the PLS rate fluctuation on the lower level of trust of the depositor in the bank. Banks are afraid of losing money when investing funds in PLSbased financing. Because when the level of PLS in the bank decreases, the benefits obtained in it becomes uncertain, all influenced by the merits of the business carried out by customers as managers of capital (mudharib). Another Islamic scholar (IS2), who is an academician, specialized in Islamic finance, stated:

"... the PLS ratio will also affect the demand at the bank. Even though the ratio determined by the Islamic banking does not change ... the PLS ratio might be different from one to another type of business carried out by the bank' customers who are financed by the bank using PLS-based products, but the PLS ratio did not change over the financing contract period."

In addition to losing trust from the depositor, the bank is also afraid of the risk of capital loss or called an asset loss. Because in PLS-based financing of mudharabah, especially full venture capital from banks (full-equity based investment), customers are only as capital managers (mudharib). Then there is also no collateral in the PLS-based financing so that banks in addition to reducing flexibility in using bank funds are also at great risk of losing capital when the business financed by the bank fails. This is as stated by Islamic scholar (IS3), who is a shariah supervisory board member:

"So, if you are giving a loan to someone, then the asset loss is the assets given as collateral or as mudharabah, there is no need for collateral. Because mudharabah is essentially imposes no collateral. When there is no collateral, it turns out all the funds are a loss. When all the funds are lost due to negligence or as something else, then the risk is very high."

Of course, in the filing of PLS-based financing, the purpose of the bank is to avoid the risk of failure that will result in large losses to the bank, so that in minimizing the risk, the bank does not arbitrarily provide financing for this outcome. Because when businesses run by customers go to bankruptcy or not successful, the bank will occur bad financing, default, and even loss of capital. So, in this case, the bank prioritizes the filing of financing for businesses that have been experienced and the business has been proven successful for several years. This was stated by a bank customer ( $\left.\mathrm{BC}_{1}\right)$, who has experience of granting PLS-based financing, as below:

"Because Islamic banks do not want or do not yet dare to use the mudharabah and musharakah PLS agreements. In terms of the efforts of the customer is still not tested its success or wellknown. So, banks do not want to lose because 
there is a risk, so the bank offers murabahah financing".

Other bank customers also stated:

"In proposing PLS-based financing, surely the proposed business must have a good experience or track record. In fact, the customer is very eager to propose PLS-based financing, it is just that it is constrained because the business that the customer is running is not going well and the bank is at risk of loss. Thus, the bank will be a reluctance to provide us the PLS-based financing, because when our business going to fail, the bank does not bear the loss" (BC2).

"The Islamic bank prioritizes to earn maximum profit by avoiding risk. This causes the bank to offers PLS-based products. It is really unfair and un-Islamic. The bank only wants profit, but avoid taking the risk. The bank is only willing to provide us mudharabah or musharakah financing for our business that has been proven profitable. For a new start-up business, let alone the micro-smallmedium enterprises, it is very hard and almost impossible to get financing from the bank unless there is regulation required the bank to give us financing" $\left(\mathrm{BC}_{3}\right)$.

The above opinions conclude that the bank is unwilling to use PLS-based financing because the bank does not want to bear large losses, including the bank fearing the risk of losing trust from the depositors when the PLS rate or ratio at the bank decreases, then the bank is also afraid of the occurrence of bad loans, failed to pay, and banks are also afraid of losing capital (asset loss) when a business that is run by customers fails because the businesses submitted by customers are uncertain of success, customers who apply for financing do not have good business experience. Thus, the opportunity for banks to incur losses is huge since the Islamic bank should not impose collateral for the PLS-based financing. Therefore, bank strongly prevents or avoids using the PLS-based financing due to some of these risks, findings similar to the studies by Ascarya \& Yumanita (2005) and Adnan \& Purwoko (2015).

Nevertheless, banks should channel their funds more to the productive sector using PLSbased financing, even though murabahah financing is safer and less risky. However, the bank plays an important role in developing community economic growth, because the money circulating in the community is increasing. This is as stated by one of Shariah Supervisory Board member, as below:

"And it is not productive, if for the safety of the bank okay. But this bank is not only a goal for self-safety, but it must also grow the people's economy. As the community's economy grows, banking activities will also be better. When there is a lot of money in society, the business will grow up and the economy will be enhanced and people will demand more for financing, thus make banks become better and stronger " (IS2).

The lack of experience and expertise of Islamic Human resources (IHR) or Islamic bankers is a problem that occurs at BSA. Almost all existing IHR did not come from Islamic economics graduates. Moreover, BSA is an exconventional that has recently been converted from a conventional bank to a full-fledged Islamic bank, thus, automatically, the existing IHR did not yet have the special capacity as an Islamic banker in handling, processing, and overseeing PLS-based financing. Their mindsets are still conventionally oriented. This is in accordance with what was conveyed by one of the top managers of the bank, specialized in financial services authority and supervision division: 
"The problem is also the competence of IHR entering Islamic banks that also cannot support the implementation of monitoring and communication with debtors effectively and there is no efficient. Because why? The Islamic bank industry is still young, still new, especially our bank. Maybe his understanding of sharia is still limited and looking for IHR that has sufficient competence to understand technical bank regulations, prudential or risk management and also understanding Shariah is difficult" (IB1).

Indeed, the IHR of Islamic bank who really understand the Islamic finance and banking system is very rare. This is as revealed by a customer of the bank ( $\left.\mathrm{BC}_{2}\right)$ :

"Islamic Human Resources in Islamic bank are lacking knowledge and practices on Islamic finance and banking. They do not really understand the Islamic bank well. Because most of them who work in Islamic bank having an educational background from conventional economics, finance, and banking. If there are IHR who have the relevant educational background to the Islamic bank, it is estimated only about 10\%."

In addition, in terms of quantity, IHR of BSA is still lacking, the number of IHR that can handle PLS-based financing properly is very minimal so that when customers come to apply for financing, it cannot be processed quickly. This is as revealed by another top manager of the bank, who is specialized in the financing division, as follows:

"The constraints of the internal banks here may be the number of IHR that is still lacking, officers who are specifically tasked with finding customers for these PLS-based products are relatively lacking, here are only five people and it is still lacking, sometimes when customers are coming, we cannot process it quickly because sometimes we still need taking care of the others. Then the second reason may also be the ability of IHR is inadequate because they are not from a graduate of Islamic Economics, Finance, and Banking" (IB2).

The above statements are in line with the previous study by Prasetyo and Burhan (2012) and Adnan and Purwoko (2015), that in the internal aspects of banks, the factors that influence the low volume of PLS-based financing are the lack of understanding, quality, and quantity of IHR in Islamic banking.

Handling PLS-based financing is not as easy as handling Non-PLS-based financing products. For example, in the Non-PLS product of murabahah financing, the bank is more certain in determining the price and profit to be gained. Meanwhile, in PLS-based financing, the role of the bank is only as capital owners (shahibul maal), the limited role of banks as investors. The Shariah Supervisory Board member said:

"If from the public, the customers ask for financing with a murabahah contract, it is easier and simpler. Why? Because murabahah financing provides a guarantee for the bank when customers are getting financing for consumptive purposes. If the bank uses murabahah financing, it tends to be more safety, is not that right? For example, the consumption of civil servants, that is the most dominant financing provided by the bank using murabahah contract" (IS2).

Moreover, to reduce the risk of bank losses, the bank must be able to supervise and monitor to ensure that the business run by the customer smoothly and when the customer fails, the bank must be ready to guide the customer so that the customer's business is successful. But in the process of controlling and supervising the customer's business, the bank must incur significant operational costs and take a long time, especially in the case of mudharabah financing. This has caused banks to be reluctant to implement PLS-based 
financing and divert it to Non-PLS financing of murabahah. This is as stated by the top manager of the bank, who is specializing in supervision of the financial services authority division, as below:

"The bank must provide guidance, proper monitoring. If the bank wants to distribute PLS-based financing, the bank must always standby together with the customer (the debtor) to oversee the debtor, to oversee the business of the customer" (IB1)

This is in line with the opinion of the Islamic scholar, who stated that:

"So as long as this IHR is more watched from the office, even though if they have applied the principle of PLS-based financing they must be ready to review the customer's business directly to the field. Because when the customer fails, it must be ready to be guided by the bank as well, so that the customer's business becomes successful. Maybe, IHR doesn't exist yet for overseeing the customers' business on site. Then the second is high operational costs, because if the principle of PLS-based products bank he must control and supervise the customer to ensure that his business will be successful. So the bank must go to the field directly and it will cost more" (IS1).

In the handling of PLS-based financing, in addition to being complicated, it also requires large operational costs in monitoring the customer's business. The PLS-based financing operational cost cannot yet be measured, thus requires a more critical analysis system. This is as opined by one of the bank managers, specializing in financing division, as below:

"Because, in financing these PLS products, it cannot yet be measured, automatically something that we already know with something that we have not measured will be different, the way we react will also be different as if we cannot project it. So, this financing is more complicated and riskier... " (IB3).

Complicated handling of PLS-based financing causes banks to be reluctant to offer more of these products to customers. On the other hand, handling murabahah financing is easier; the bank could transfer all forms of financing to murabahah contracts. Thus, when handling the PLS-based products is complicated, it will automatically require a large handling fee as well. This finding is supported by the previous studies conducted by Ascarya and Yumanita (2005) and Adnan and Purwoko (2015).

The lack of PLS-based financing products offered by the Islamic bank as compared to other Non-PLS-based financing is due to difficulties in handling PLS-based products and they are also uncertain. Moreover, the Islamic bank is now faced with increasingly fierce competition with conventional banks. Conventional banks that offer innovative and cheaper products would be a challenge for the Islamic bank to win the competition. Thus, Islamic bank tends to leave away the PLS-based products that are expensive and complicated and, instead, offers alternative financing with lower risks, namely murabahah financing. Therefore, banks do not dare to use this PLSbased financing which is at high risk because it will result in stunted growth of the bank itself. This is as opined by one of the bank managers from the division of Finance, as follows:

"Compared to murabahah, surely musharakah is more risky, complicated, and costly. Thus, for the bank, it will be more interesting to offer murabahah. The PLS-based products are less innovative as compared to various non-PLSbased products. We also still have to develop our products so that we do not only race on murabahah. So there must be PLS-based product innovation."(IB2). 
In addition, the bank is also less serious in offering the PLS-based products, thus their innovation. Meanwhile, the PLS-based products should be more superior and effective in their application so that they could contribute to enhancing the productive sector in the bank itself and can foster community economic development. An Islamic scholar from Islamic State University of Ar-Raniry (UIN Ar-Raniry) opined that:

"Banks now are like cooperatives, there is not the slightest effort for innovation. So what is done is only selling vehicles for employees who do not want to face challenges. Banks only think that there must be money coming in, banks should think that in the real sector, banks are less supportive of community businesses, banks only support consumptive people. So there is no economic growth because there is no innovation there is only the transfer of money from one person to another. Bank does not have anything or does not play a role in economic growth" (IS1).

In line with the above-mentioned opinions, in his study, Majid (2014a) and Anwar (2016) stated that competition in financial institutions is very aggressive and tight, this has been pressing Islamic banks to offer products that are profitable and less risky rather than having to use products with the high cost and riskier. The existing completion in the banking industry has forced Islamic banks to provide alternative financing that is less risky, especially murabahah. Offering more mudharabah financing causes the Islamic bank into a high risk and costly transactions, the practices that the bank always strives to avoid losses to maximize profit.

The other factor that influences the lack of PLS-based financing is asymmetric information. This happens because of differences in information obtained between the Islamic bank and the customer (Zafar \& Siddiqui, 2019). In this case, the customer knows more about the condition of the business he is running compared to the Islamic bank. Consequently, the possibility of deviations by the customer is very large. An Islamic economic scholar from the Islamic State University, UIN Ar-Raniry opined that:

"Called counterpart risk, how the trust of the bank in a customer, while the customer does not keep and obey that trust might put the bank into a problem. It also becomes very fragile in the banking system. So, this is the risk of the most feared of which is most feared by the banks" (IS3).

The PLS-based financing requires transparency between the two parties, but what happens by their customers is not honest in reporting the results of the business being run. This causes a lack of trust from the bank to the customer and the bank is always careful and always monitors the development of the business that is run by the customer. One of manager, specialized in the supervision of the financial services authority opined that:

"The PLS-based financing requires transparency from both parties, we have also regulated the bank regarding transparency and accountability. Likewise, the customer of financial services from Islamic banking must also be transparent if he receives PLS-based financing products. What should be done at the bank due to this asymmetric information? It is often when we read the financial services industry statistics for financial results for the results are often problematic. Because why? Information held by the debtor (bank customer) is not forwarded sufficiently to the bank. The hope is that the bond between the bank and the debtor for this PLS-based financing should be very close. In this contract, honest customers periodically inform the bank how much profit or loss he/she earns" (RG1). 
This asymmetric information is a problem for banks because in PLS-based financing there should be transparency between the two parties so that customers do not report only losses and manipulate profits so that banks will experience losses. Bank tends to fear the risk of customers who commit fraud and non-transparent, so banks avoid offering PLS-based financing. This is in line with what Adnan and Purwoko (2015) and Zafar and Siddiqui (2019) statements are that the transparency of customer is one of the factors affecting the low volume of PLSbased financing products offered by the bank. In many cases, the dishonesty of the customers in reporting their business performance has put the bank into the problem.

The sixth factor that causes a lack of PLS-based financing offered by the Islamic bank is the lack of socialization by the bank to the public. The bank should socialize the PLS-based financing products so that the public understands that these products are totally different from the conventional bank's interest system. The Islamic scholar who is also the Shariah supervisory board member opined that:

"One of the factors in our Islamic banking is that our ability to socialize to the PLS-based product to the community is very limited". The public sometimes confuses various products of Islamic bank and they are in difficulty to differentiate one Islamic product to another. Not only that, most of the people even still perceived that Islamic banking products are not much different from the products of a conventional bank, the only difference is only the name of products that are named in the Arabic terminology" (IS2).

Similarly, another Islamic scholar opined that:
"To make the public more aware of PLS-based financing product, the IHR of Islamic bank must often go to the field to socialize so that customers understand and want to take musharakah financing. The public should be made aware of the Islamic banking products that the PLS-based financing products that are totally different from the products offered by its conventional counterparts and they are better than conventional systems." (IS3).

In short, Islamic banks should pay more attention to the public by socializing the existing system and products offered by Islamic banks. The community plays an important role in PLS-based financing, thus their understanding and knowledge about Islamic banking are important. With the socialization of Islamic banking, when the public understands the Islamic banking system, the public will definitely prefer to use the PLS-based financing products.

After discussing the causes of lack of PLSbased financing from the internal bank perspective, the causes of the external aspects of the bank are now discussed. Three main causes are identified as opined by informants.

First, The existence of the moral hazard. From the customer perspective, the first problem that causes the reluctance of Islamic banks to offer more PLS-based financing is the moral hazard of the customer. The customers are reluctant to submit financial reports and tend to hide actual profits. This is a problem due to the dishonesty of customers because they do not want to share profits with banks. The Islamic scholar from the UIN Ar-Raniry opined that:

"Banks are worried about the moral hazard of customers. When there is a profit, for example, they do not report to the bank, but when there is a loss, they report it. Therefore, the bank prefers not to channel funds into PLS-based financing. The customers also do not want to share their 
business income statement with the bank, for example, if business owned by them can get more profit, the customer wants to enjoy it himself and do not want to share with the bank" (IS3).

In addition, banks are also concerned about the misuse of funds due to the dishonesty of customers. When funds are given, customers use the funds for other purposes. In this case, the moral hazard factor has significantly influenced the low volume of PLS-based financing at the BAS, as opined by the manager of the bank, specialized in financing division:

"The misuses of funds by customers have been a problem for us when providing the public the PLS-based products. Customers are ready not to report every month how much income is, how much profit is, not until when the profit is said to be a loss, then it affects the risk of financing. So, here dishonesty or moral hazard of customers is very high" (IB3).

The above-mentioned opinions that moral hazard is one of the causes of lack of PLS-based financing offered by Islamic bank is in line with the finding of previous studies by Prasetyo and Burhan (2012) and Adnan and Purwoko (2015) who found that PT. Bank BRI Syariah, Malang Branch and the BPRS in Yogyakarta, respectively, have also experienced moral hazard problems. Moral hazard is a problem that has arisen when bank customers (mudharib) misuse the PLSbased financing funds for other purposes that are not agreed in the financing contract.

The second reason for the lack of PLSbased financing in Islamic banks is due to the lack of public understanding of the products. The public does not understand the existing financing system in Islamic banks. Many of them still perceive that Islamic banks are the same as conventional counterparts. Thus, the public who are familiar with conventional banks is reluctant to switch to Islamic banks for financing. This is as opined by one of the Shariah supervisory board members, as below:

"But sometimes customers (external factors), for example, do not understand the Islamic banking products, their level of knowledge is very low ... Common constraints, for example, are the views of the misleading community, they perceived that PLS-based products are still similar to conventional bank practices and they are also difficult to obtain.... they do not understand well..." (IS2).

Islamic bank pays considers seriously the issue of moral hazards of customers, thus implement strict requirements for the customers to be financed using the PLS-based products. This lack of public understanding and their dishonesty greatly influences the progress of PLS-based financing in an Islamic bank. To overcome this issue, the bank could conduct more complex outreach to the public so that the public can really understand the financing system in Islamic banking. Because the role of the community is very important when people understand the Islamic bank and finally will definitely select Islamic banks for them to get financing. Another Islamic scholar, who is a professor in Islamic economics from the UIN Ar-Raniry opined that:

"Therefore, in terms of PLS financing, it is actually less understood by customers about how to negotiate profits. But, I am sure that in the next 20 years, when customers understand mudharabah and musharakah, the community already understands the system, the community will ask for them because he will not accept the risk if the bank really adheres to the PLS-based system" (IS1).

This is in line with the previous studies conducted by Ascarya \& Yumanita (2005) and Adnan \& Purwoko (2015), who stated that the factors causing the lack of PLS-based financing by Islamic banks include the lack of people's understanding of mudharabah. He further 
claimed that this case is not only in mudharabah but also in other Islamic banks' financing products. Public knowledge has been still lacking, they still perceive and think that Islamic banks are not much different from their conventional counterparts.

The last factor causing the lack of PLSbased financing products from the external bank perspective is the low demand of PLSbased products from the customers. The Islamic scholar opined that:

"...It is only a small amount of demand for PLS-based financing products. So that causes low PLS-based financing due to lower demand of customers. This can be seen from the Islamic bank composition of financing, the PLS-based financing always the lowest one compared to other Non-PLS-based financing products" $\left(I_{3}\right)$.

The low demand of PLS-based products might be caused by several reasons. It might be because the customer is less interested, or the customer does not want to share the profits with the bank, the customer does not want to share the profits with the bank, or maybe also because the customer does not understand the related financing available at the Islamic bank.

However, to the bank customers, their low demand for the PLS-based financing product is due to the difficulty they experience in getting such financing. The terms and conditions and requirements for getting financing are complicated and take a longer process for approval. This is as opined by one of the Islamic bank customers, as below:

"The main reason why we demand less for the PLS-based financing products is simply due to complicated requirements regulated by the bank. Bank will ensure our business that we apply for financing producing sustainable profit; otherwise, the bank will not consider and approve our financing proposal. In addition, the process of approval is also taking a long time. That is why we think that Islamic bank has no different from conventional bank" $\left(\mathrm{BC}_{3}\right)$.

The above opinion also shows that the customer perception of similarity between Islamic banks and conventional banks causing low confidence of customers in an Islamic bank. In addition, customer needs are also influential factors, because customer demand is according to needs. Inevitably the consumptive behavior of the community causes them to use more funds from bank financing for consumption (Bidabad, 2019), such as to buy houses, cars, and other vehicles, house furniture and so on. The demand for bank funding to these consumptive purposes contains a higher risk of financing defaults, thus to avoid this problem, the bank prefers to provide the Non-PLS-financing such as murabahah that is less risky and gives bank more certainty of profits (Nor \& Ismail, 2020), in line with customer's needs. This is as opined by the one of middle manager of the Islamic bank, specialized financing division:

"So the lack of PLS-based financing has an effect on customer needs/demand. Because demand depends on needs. That is why murabahah is the most popular financing in our bank? Because of this, the first of our people in Aceh is still consumptive enthusiasts. Murabahah is the most savior product for us. We need to ensure profit for our sustainability" (IB3).

From a regulatory point of view, the main problem causing a lack of PLS-based products offered by Islamic banks is the lack of support from regulators. Thus, to increase PLS-based financing products, supporting policies from the regulator are needed. Regulators are less assertive by providing supporting policies such as what percentage of the provision PLS-based financing and it has imposed double tax incidences from the Islamic banking products 
(Ascarya \& Yumanita, 2005). The Islamic scholar from UIN Ar-Raniry opined that:

"The regulator is only limited to just supervising and appealing. But it is all up to the bank itself. If the bank wants mudharabah, please. If the bank wants murabahah is also, please. The regulators do not say what should be prioritized. No regulation regulates the portion of PLS-based financing that must be applied by the bank for each year. So, the lack of regulator support and no tax incentive for Islamic bank causes PLS-based product cannot run well" (IS3).

Thus, the role of regulators is crucial in promoting PLS-based financing of Islamic banks. If there is no supportive policy, the bank will continue to use Non-PLS-based products of murabahah that is more certain and low risk. The principle of PLS-financing is a major milestone of Islamic banks that need strong support from the government. However, without a bank regulation policy, the bank has no incentive to offer PLS-based products. The Islamic scholar, who is also the Shariah supervisory Board member of the bank opined that:

"Their role is crucial; the PLS-based financing is very dependent on regulations. The regulator, in this case, is the Financial Services Authority (OJK). In the context of Islamic financing, there is a link with the National Shariah Supervisory (DSN-MUI) fatwa. So, this role is very important if there is no DSN role, there is no DSN Fatwa, the public still doubt whether the Islamic banking products it is Islamic or not. but even if there is no OJK regulation, there is no umbrella, no framework ... Therefore, the components of these two must really provide guarantees so that the PLS-based financing can develop properly" (IS2).
The above-mentioned opinions are in line with the findings of the study by Ascarya and Yumanita (2005) who stated that the main problem of the lack of PLS-based financing is caused by unsupportive Islamic banking regulations. The incentive system, the minimum standard for Islamic bank managers, and directed market-driven strategy should be regulated as for the development of Islamic banks to stay on its Islamic tracks that make Islamic banks be able to contribute positively to the economic development by reducing poverty and income disparity, and offering more job opportunities for unemployed population in Indonesia (Majid, 2017).

Table 3 summaries the causes of lack of PLS-based financing products offered by BSA, based on the opinions of the Islamic scholars, Islamic bankers, Islamic bank customers, and regulators viewed from the perspectives of internal and external Islamic banks as well as regulators.

As illustrated in Table 3, the internal aspects of the Islamic bank, that is high risk is found to be the most dominant cause of lack of PLS-based financing at the BSA. However, in fact, if seen more clearly, this factor is not a reason for banks to abandon PLS-based financing if the bank innovatively improves PLS-based products so that the risk contained in the products could be minimized and customers will be more interested in them (Majid \& Zulhanizar, 2016).

Various socialization programs should be more progressively initiated and the introduction of PLS-based financing products to the public with the main purpose to improve public understanding and knowledge on the unique characteristics of Islamic banking products that are totally different from the products offered by conventional banks (Latif, 2019). If both parties between the bank and the customer already truly understand the related PLS-based financing products, these products would be able to develop and dominate the 
products of BSA, as urged by many contemporary Islamic economic scholars (Chowdhury et al., 2019).

These PLS-based products are fairer, where the profits or losses are shared between the parties. If between the parties could exchange ideas based on shura (mutual consultation) principles related to the customer's businesses financed by the bank, the business would surely avoid the dreaded risks, and the business would run successfully and gain even more profits. Karim (2001) stated that profits or losses arising from business activities are borne jointly based on an agreed ratio. In the PLS-financing products, there are no pre-determined fixed returns as interest (riba), but they have a shared ratio between bank and customer based on the profitability of the business.

Table 3. Summary of Informants' Perception of the Lack of PLS-based Financing Products

\begin{tabular}{|c|c|c|c|c|c|}
\hline \multirow[b]{2}{*}{ Aspect } & \multirow{2}{*}{$\begin{array}{l}\text { Causes of lack of PLS-based } \\
\text { product of Islamic bank }\end{array}$} & \multicolumn{4}{|c|}{ Informants } \\
\hline & & $\begin{array}{l}\text { Islamic } \\
\text { Scholars }\end{array}$ & Customers & $\begin{array}{l}\text { Islamic } \\
\text { Bankers }\end{array}$ & Regulators \\
\hline \multirow{6}{*}{ Internal } & 1. High risk & $\sqrt{ }$ & $\sqrt{ }$ & $\sqrt{ }$ & $\sqrt{ }$ \\
\hline & 2. Low quality of Islamic bankers & $\sqrt{ }$ & $\sqrt{ }$ & $\sqrt{ }$ & $\sqrt{ }$ \\
\hline & 3. Complicated handling & $\sqrt{ }$ & - & $\sqrt{ }$ & $\sqrt{ }$ \\
\hline & 4. Lack of product innovation & $\sqrt{ }$ & - & $\sqrt{ }$ & $\sqrt{ }$ \\
\hline & 5. Asymmetric information & $\sqrt{ }$ & - & $\sqrt{ }$ & $\sqrt{ }$ \\
\hline & 6. Lack of socialization & - & $\sqrt{ }$ & $\sqrt{ }$ & - \\
\hline \multirow{3}{*}{ External } & 1. Moral hazard & $\sqrt{ }$ & - & $\sqrt{ }$ & $\sqrt{ }$ \\
\hline & 2. Lack of understanding & $\sqrt{ }$ & $\sqrt{ }$ & $\sqrt{ }$ & $\sqrt{ }$ \\
\hline & 3. Lack of demand & $\sqrt{ }$ & - & $\sqrt{ }$ & $\sqrt{ }$ \\
\hline$\overline{\text { Regulation }}$ & 1. Lack of supportive regulation & $\sqrt{ }$ & $\sqrt{ }$ & - & - \\
\hline
\end{tabular}

Furthermore, to avoid the high risk of the PLS-based products, Islamic banks could overcome if Islamic banks really provide financing to customers following what is needed, then it will be certain that the total portion of the financing in BSA will be as reasonable as it should be. But what is happening now, in practice, the bank always avoids the risks of PLS-based products for reasons of fear of harming the bank (Zaaba \& Hassan, 2019; and Nor \& Ismail, 2020) so that the bank issues financing that is not what the customer needs, such as impressing the customer by offering other Non-PLS financings of murabahah that has lower risk. This makes the mudharabah and musharakah increasingly abandoned by banks.
Viewed from the external aspect of the bank, the low understanding of the community that caused low demand for the PLS-products offered by Islamic bank could be overcome by the way the public is expected to find out and better understand the related PLS-based Products, following the socialization programs conducted by an Islamic bank (Latif, 2019). If the community has understood well the Islamic banking products, the public would perceive that the Islamic bank is totally different from the conventional counterpart, making the public more prefers to deal with Islamic banks rather than conventional banks. The public has a better understanding that the interest-based products of the conventional bank are a form of usury that is forbidden in Islam, while in the Islamic bank using the principle of PLS that is 
fair, the benefits and losses are shared together, no one party is disadvantaged, and they are free from riba. Mansour (2019) stated that the financing of musharakah and mudharabah is the cooperative contracts in certain businesses carried out between two or more parties jointly contributing funds with an agreement that the benefits and risks will be shared together following the agreed PLS-ratio.

Finally, from the regulatory aspect, support from regulators is strongly needed in the development of PLS-based financing (Nastiti \& Kasri, 2019). Banking regulators, OJK, for example, are expected to be able to provide supporting policies, such as establishing rules that each Islamic bank must offer at least $50 \%$ of their financing based on the PLS-products. This was done to encourage PLS-based financing to dominate Islamic banking products (Ascarya \& Yumanita, 2005), especially BSA that is operating in Muslim dominated Province of Aceh, Indonesia that has implemented Islamic law in all aspects of life. PLS-based products, finally, would drive the real sector of the economy and contribute to alleviate the high poverty level, reduce high levels of employment and income disparity in the province. In the end, the Islamic bank could solutions for economic problems and would further realize the prosperity of people's economy, as urged by many scholars (Majid \& Kassim, 2015)

\section{CONCLUSION}

This study identified and descriptive discussed factors influencing the reluctance of the Islamic bank to offer more PLS-based financing products, taking the case of PT. Bank Aceh Syariah in Indonesia. Using a grounded theory approach, this study interviewed relevant informants who are knowledgeable in Islamic banking theories and practices, including experts, practitioners, customers, and regulators. In this study, the problem of the low volume of PLS-based financing products is viewed from three aspects, namely: internal, external, and regulation.

They concluded that, from the internal aspect, the problem of the low volume of PLSbased financing products is caused by six factors, namely: high risk, lack of quality and quantity of human resources, complicated handling, lack of banking product innovation, asymmetric information, and lack of socialization. Meanwhile, from the external aspects, the low volume of PLS-based financing is caused by three factors, namely: moral hazard, lack of community's knowledge on Islamic banking products, and low demand. Finally, from the aspect of the regulation, the low volume of loss and PLS-based financing products is caused by a lack of support from the regulator.

Based on these findings, the study suggested for the Islamic bank to develop and innovate its products to minimize the risk, as well as to socialize to the community so that they understand and have a vast knowledge of the products of Islamic banking. Islamic banks should also increase the understanding and the quality of Islamic human resources by allocating sufficient budget for short- training and longterm education, introducing an incentive scheme and requiring managers of Islamic banks to fulfill the minimum standard via periodical fit and proper tests. The regulators are advised to enhance more supporting policies to encourage the growth of PLS-based financing products such as the collectability classification of PLS financing and initiating incentive system to the Islamic bank that offers PLS financing. By implementing all these suggestions, the Islamic bank with its PLS-financing could finally enhance the public economic welfare shortly. 
Further studies on this topic could provide comprehensive findings by interviewing more informants across the areas in Indonesia and more variety of financing products offered by all Islamic banks in Indonesia. A mixed-method, combining qualitative and quantitative approaches to research the issue is also believed could provide comprehensive and robust findings.

\section{REFERENCES}

Adnan, M. A. \& Purwoko, D. (2015). Analysis of the factors that influence the low mudharabah financing according to the perspective of Islamic bank management with a critical approach. Journal of Accounting and Investment, 14(1), 13-31.

Andraeny, D. (2011). Analysis of the influence of third party funds, profit sharing rates, and non-performing financing on the volume of profit-sharing based financing on Islamic banking in Indonesia. Simposium Nasional Akuntansi XIV, 47-53.

Annisa, L. N. \& Yaya, R. (2015). The influence of third party funds, profit sharing rates and non-performing financing on the volume and portion of profitsharing based financing on Islamic banking in Indonesia. Share: Jurnal Ekonomi dan Keuangan Islam, 4(1), 79-104

Anwar, M. C. (2016). Analysis of the factors causing the low interest in using mudharabah financing. IAIN Tulungagung.

Aprilia, S. \& Mahardika, D. (2019). Factors affecting profit sharing financing at Islamic commercial banks in
Indonesia. Jurnal Riset Akuntansi Kontemporer, 11(1), 9-15.

Ascarya, A. (2014). Sharia Banking Contracts and Products [Akad dan Produk Perbankan Syariah]. Jakarta: PT. Raja Grafindo Persada.

Ascarya, A. \& Yumanita, D. (2005). Looking for low solution for profit sharing financing in Indonesian Islamic banking. Buletin Ekonomi Moneter dan Perbankan, 8(1), 7-43.

Bank Aceh Syariah (2020). Annual Report: 20172019. Banda Aceh. Available at: http://www.bankaceh.co.id/?cat=9.

Beik, I. S. (2006). Islamic Banks and Real Sector Development [Bank Syariah dan Pengembangan Sector Riil]. Jakarta: Pesantren Virtual.

Bidabad, B. (2019). Economic-juristic analysis of usury in consumption and investment loans and contemporary jurisprudence shortages in exploring legislator commandments. International Journal of Islamic Business \& Management, 3(2), 115.

Birks, M. A\& Mills, J. (2015) Grounded Theory: A Practical Guide. USA: Sage.

Choirudin, A. A\& Praptoyo, S. (2017). Analysis of factors affecting mudharabah profit sharing financing at Islamic commercial banks. Jurnal Ilmu dan Riset Akuntansi, 6(9), 23-41.

Chowdhury, A. H. M. Y., Saba, N. \& Habib, M. (2019). Factors affecting the choice of Islamic banking by the customers: A case study. 3(1), 1-5.

Ministry of Religion of the Republic of Indonesia. (2005) Al-Quran and Translation. Jakarta: CV. J-ART. 
Imam, P. \& Kpodar, K. (2016). Islamic banking: Good for growth?. Economic Modelling, 59, 387-401. doi: 10.1016/j.econmod.2016.08.004.

Karim, A. (2001). Islamic Economics: A Contemporary Study [Ekonomi Islam: Suatu Kajian Kontemporer]. Jakarta: Bina Insani.

Karim, A. (2010). Islamic Bank Fiqh and Financial Analysis [Bank Islam Analisis Fiqh dan Keuangan]. Jakarta: Raja Grafindo Persada.

Kassim, S. (2016). Islamic finance and economic growth: The Malaysian experience. Global Finance Journal, 30, 66-76. doi: 10.1016/j.gfj.2015.11.007.

Khanifah, Z. (2015) Analysis of factors affecting the level of profit sharing financing at Mega Syariah Bank in 2010-2012. IAIN Tulungagung.

Latif, S. D. H. (2019). Awareness and Perceptions of Muslim Society towards Islamic Banking in the Philippines. IJIEF:International Journal of Islamic Economics and Finance, 1(2), 209-228. doi: 10.18196/ijief.1211.

Majid, M. S. A. (2011). Grounding Islamic Banking in "Bumoe Syariah". Aceh Economic Review, 16-19.

Majid, M. S. A. (2014a). Contemporary Islamic Economics. [Ekonomi Islam Kontemporer]. Jakarta: Laznas BMT.

Majid, M. S. A. (2014b). Sharia banking regulations: Comparative study between Malaysia and Indonesia. Medias Syariah: Wahana Kajian Hukum Islam dan Pranata Sosial, 16(1), 231-254.

Majid, M. S. A. (2017). Eradicate poverty of the people of Aceh with sharia. Medias Syariah: Wahana Kajian
Hukum Islam dan Pranata Sosial, 15(2), 209-220.

Majid, M. S. A. \& Kassim, S. H. (2015). Assessing the contribution of Islamic finance to economic growth: Empirical evidence from Malaysia', Journal of Islamic Accounting and Business Research, 6(2), 292-310. doi: 10.1108/JIABR-07-20120050.

Majid, M. S. A. \& Zulhanizar, S. (2016). The patronage behaviour of Islamic bank's customers: Empirical studies in Aceh. Al-Iqtishad: Jurnal Ilmu Ekonomi Syariah, 8(2), 201-212.

Mansour, I. H. F. (2019). Customers' perceptions of selection criteria used by Islamic bank customers in Sudan: The importance of Shariah compliance. Journal of Research in Emerging Markets, 1(4), 41-53.

Miles, M. B., Huberman, A. M., \& Saldana, J. (2014) Qualitative Data Analysis: A Methods Sourcebook. CA: Sage Publications Ltd.

Nabhan, F. (2010). Profit lost sharing: Solusi ekonomi Islam menghadapi globalisasi ekonomi. Jurnal Sekolah Tinggi Agama Islam Negeri (STAIN) Salatiga, 1(2), 279301.

Nastiti, N. \& Kasri, R. (2019). The role of banking regulation in the development of Islamic banking financing in Indonesia. International Journal of Islamic and Middle Eastern Finance and Management, 12(5), 643-662.

Nor, A. M. \& Ismail, S. (2020). Profit and loss sharing (PLS) and non-PLS Financing in Malaysia: Which one should be the one?. KnE Social Sciences, 14-25.

Nurhasanah, N. (2010). Optimizing the role of mudharabah as a contract of cooperation in the development of Islamic economics. Syiar Hukum, 12(3), 285-296. 
Prasetyo, P. A. \& Burhan, M. (2012) Identification of factors that influence the low Islamic banking profit sharing financing (Case Study of BRI Syariah Bank Malang Branch). Jurnal Ilmiah FEB, 2, 1-17.

Setiawan, I. (2019) The role of Islamic banking in the development of economic sectors in Indonesia. International Journal of Applied Business Research, 1(02), 88-99. doi: 10.35313/ijabr.viio2.70.

Sharia Banking Statistics (2020). Islamic Banking Statistics 2016-2020 [Statistik Perbankan Syariah 2016-2020]. Jakarta. Available at: https://ojk.go.id/en/kanal/perbankan l.

Warninda, T. D., Ekaputra, I. A. \& Rokhim, R. (2019). Do Mudarabah and Musharakah financing impact Islamic Bank credit risk differently?. Research in International Business and Finance, 49, 166-175. doi: 10.1016/j.ribaf.2019.03.002.

Yüksel, S. \& Canöz, İ. (2017). Does Islamic banking contribute to economic growth and industrial development in Turkey. Ikonomika, 2(1), 93-102. doi: 10.24042/febi.v2i1.945.

Zaaba, N. I. B. M. \& Hassan, R. (2019) Why Islamic banks are reluctant to offer musharakah mutanaqisah for home financing: The case of Maybank Islamic and Affin Islamic Bank. TUJISE, 6(1), 51-65.

Zafar, S. H. \& Siddiqui, D. A. (2019) Impact of Asymmetric Information in Islamic Financial contract: An Empirical Analysis. European Journal of Islamic Finance, 14, 1-18. 